\title{
OPTIMALISASI PENGELOLAAN DAYA TARIK WISATA (DTW) PADA MASA PANDEMI OLEH DISPORAPAR KABUPATEN KENDAL
}

\author{
${ }^{1}$ Suwarji, ${ }^{2}$ Maulida Putri Rahmawati \\ ${ }^{1}$ Universitas Selamat Sri ${ }^{2}$ Universitas Selamat Sri \\ suwarjiwarji29@gmail.com \\ Kendal, 5135, Indonesia
}

\begin{abstract}
The purpose of this research is to analyze and describe how optimalization management of tourist attraction during pandemic by Dinas Kepemudaan, Olahraga dan Pariwisata Kendal Regency. This study uses a descriptive qualitative method, which means that researchers get data through observation and interviews and documents about Tourist Attractions by Disporapar. The data analysis used the theory of Miles \& Huberman which consists of data reduction, data presentation, and conclusion. The results showed that Disporapar held tourism management training for tourism actors with the aim that tourism actors were able to make Kendal Regency tourist destinations known to tourists and the wider community during the pandemic. The optimization of the management of Tourist Attractions during the pandemic by Disporapar has gone well and effectively. Such as providing a place to wash hands, adjusting seating distances and requiring visitors to wear masks. Disporapar worried if this pandemic will be long over, because it affects the income of business actors.
\end{abstract}

Keywords: covid-19; kendal regency; optimization; pandemic; tourist attraction

\begin{abstract}
Abstrak
Penelitian ini bertujuan untuk menganalisis dan mendeskripsikan bagaimana optimalisasi pengelolaan daya tarik wisata pada masa pandemi oleh Dinas Kepemudaan, Olahraga dan Pariwisata Kabupaten Kendal. Penelitian ini menggunakan metode kualitatif deskriptif yang artinya peneliti memperoleh data melalui observasi dan wawancara serta mendapatkan dokumen tentang Daya Tarik Wisata (DTW) oleh Disporapar Kabupaten Kendal. Analisis data yang digunakan dalam penelitian ini menggunakan teori dari Miles \& Huberman yag terdiri dari reduksi data, penyajian data, penarikan kesimpulan. Hasil penelitian menunjukkan bahwa Disporapar Kabupaten Kendal menyelenggarakan pelatihan tata kelola pariwisata kepada pelaku wisata dengan tujuan agar pelaku wisata mampu mengangkat destinasi wisata Kabupaten Kendal dikenal oleh wisatawan dan masyarakat luas pada masa pandemi. Kemudian optimalisasi pengelolaan Daya Tarik Wisata (DTW) pada masa pandemi oleh Disporapar Kabupaten Kendal sudah berjalan dengan baik dan efektif. Seperti menyediakan tempat cuci tangan, mengatur jarak tempat duduk dan mewajibkan pengunjung untuk menggunakan masker. Disporapar Kabupaten Kendal mengkhawatirkan apabila pandemi ini akan lama berakhir, karena mempengaruhi pendapatan dari pelaku usaha.
\end{abstract}

Kata Kunci: covid-19; daya tarik wisata; kabupaten kendal; optimalisasi; pandemi

Open Access at:http://ojs.uho.ac.id/index.php/PUBLICUHO/index

Journal Publicuho is licensed under a Creative Commons Attribution 4.0 International License. 


\section{Journal Publicuho}

ISSN2621-1351 (online), ISSN 2685-0729 (print)

Volume 4 Number 3 (August - October), (2021) pp. 854-863

Accredited SINTA SK.NOMOR 28/E/KPT/2019

Open Access at:http://ojs.uho.ac.id/index.php/PUBLICUHO/index

10.35817/jpu.v4i3.19760

\section{PENDAHULUAN}

Undang-Undang Nomor 23 Tahun 2014 tentang Pemerintahan Daerah menyebutkan bahwa dalam rangka menjalankan pemerintahnya, daerah diberikan kewenangan untuk mengurus urusan rumah tangganya sendiri seluas-luasnya dalam mengatur urusan pemerintahannya menurut asas otonomi dan tugas pembantuan. Pemberian otonomi daerah seluas-luasnya kepada daerah diarahkan untuk mempercepat pembangunan daerah. Selain itu daerah juga berhak untuk menggali sumber-sumber pendapatan sendiri yang dimiliki untuk membiayai pembangunan daerah. Sumber-sumber pendapat daerah diatur juga dalam Pasal 285 Undang-Undang Nomor 23 Tahun 2014. Sumber-sumber tersebut berasal dari Pendapatan Asli Daerah (PAD), pendapatan transfer, dan lain-lain pendapatan yang sah.

Pendapatan Asli Daerah (PAD) merupakan sumber pendapatan daerah yang memiliki peran penting dalam pembangunan daerah. Pendapatan Asli daerah bersumber dari pajak daerah, retribusi daerah, hasil pengelolaan kekayaan daerah yang dipisahkan, dan lain-lain PAD yang sah (meliputi hasil penjualan kekayaan daerah yang tidak dipisahkan; jasa giro; pendaptan bunga; keuntungan selisih nilai tukar rupiah terhadap mata uang asing: dan komisi, potongan, ataupun bentuk lain sebagai akibat dari penjualan dan atau pengadaan barang dan atau jasa oleh daerah) (Enceng, 2018:54). Selain itu pemerintah daerah juga menggali potensi-potensi lain yang dapat menyumbang Pendapatan Asli Daerah (PAD). Potensi tersebut dari sektor yang dapat dikembangkan untuk meningkatkan Pendapatan Asli Daerah (PAD), diantaranya sektor pertanian, sektor pariwisata, sektor jasa, sektor perdagangan, sektor parkir, dan lain-lain.

Pariwisata di era globalisasi saat ini, merupakan salah satu sektor yang mempunyai peran yang strategis dalam menunjang pembangunan perekonomian nasional yang diharapkan mampu memberikan peningkatan pendapatan melalui penerimaan devisa negara. Kepariwisataan juga dapat memberikan dorongan dan sumbangan terhadap pelaksanaan pembangunan proyek-proyek berbagai sektor bagi negara-negara yang telah berkembang atau maju ekonominya, dimana pada gilirannya industri pariwisata merupakan suatu kenyataan ditengah-tengah industri lainnya (Pendit, 2003:33).

Undang-Undang Nomor 10 Tahun 2009 tentang Kepariwisataan menyebutkan bahwa keberadaan sektor pariwisata sangat potensial. Adanya obyek wisata yang dimiliki oleh suatu daerah, akan sangat menguntungkan dalam meningkatkan pendapatan daerah, membuka lapangan pekerjaan, meningkatkan taraf hidup masyarakat, serta meningkatkan rasa cinta untuk melestarikan lingkungan alam dan budaya yang ada. Hal tersebut tentunya akan memberikan banyak pemasukan bagi daerah yang sadar akan potensi yang dimiliki. Meski sektor pariwisata hanya menyumbang sedikit namun harapannya sektor tersebut 
dapat meningkatkan pendapatan daerah secara bertahap. Oleh karena itu untuk meningkatkan pendapatan daerah dari sector pariwisata dibutuhkan manajemen dan tata pengelolaan pariwisata yang diperankan oleh segenap pemangku kepentingan (stakeholders) baik dari unsur pemerintah maupun masyarakat.

Sektor pariwisata saat ini merupakan sektor yang terus dikembangkan dan dikelola pemerintah terutama oleh pemerintah daerah. Dimana pariwisata sebagai salah satu potensi unggulan sebagai penyumbang pendapatan daerah. Hal ini Perlu adanya pengelolaan secara tersusun dan terencana agar memperoleh hasil yang optimal bagi daerah dan layak menjadi potensi unggulan. Pengelolaan potensi wisata yang dimiliki terus dilakukan untuk meningkatkan Pendapatan Asli Daerah (PAD) di beberapa daerah kota/kabupaten, tidak terkecuali di Kabupaten Kendal. Kabupaten Kendal merupakan salah satu daerah tujuan wisata di Provinsi Jawa Tengah yang mempunyai potensi wisata yang cukup bagus. Beberapa tempat wisata yang ada di Kabupaten Kendal antara lain obyek wisata Curug Sewu, Pantai Sendang Sekucing, Kolam Renang Boja, Tirto Arum, Santoso Stabel, dsb. Pemerintah Kabupaten Kendal tengah gencar melakukan pengembangan pariwisata yang menjadi potensi dalam meningkatkan pendapatan daerah. Perkembangan pariwisata Kabupaten Kendal yang baik dapat meningkatkan pendapatan dari bantuan kontribusi sektor Pariwisata, diharapkan Kabupaten Kendal mampu memunculkan persaingan suatu daerah (Radika: 2019).

Pandemi covid-19 yang dimulai pada bulan Maret 2020 silam tentunya sangat mempengaruhi daya tarik wisata Kabupaten Kendal. Semenjak adanya pandemi pemerintah pusat mengeluarkan kebijakan pembatasan sosial untuk mengurangi penyebaran Covid-19. Tentunya hal ini sangat berpengruh terhadap objek wisata di Kabupaten Kendal selama pandemi, karena objek wisata berperan sebagai pemasukan tertinggi keuangan daerah. Berdasarkan Peraturan Daerah Nomor 76 Tahun 2016 tentang Kedudukan, Susunan Organisasi, Tugas dan Fungsi, serta Tata Kerja pada Dinas Kepemudaan, Olahraga, dan Pariwisata Kabupaten Kendal Pasal 16 menyatakan bahwa kepala bidang pariwisata mempunyai tugas melaksanakan sebagian tugas Kepala Dinas dalam perumusan kebijakan teknis, pengoordinasian, pembinaan, pengawasan, pengendalian, pengelolaan, fasilitasi, evaluasi, dan pelaporan kegiatan di bidang pariwisata. Dengan adanya tugas tersebut kepala bidang pariwisata memiliki fungsi salah satunya yakni melakukan pembinaan, pengawasan, dan pengendalian kegiatan di bidang pariwisata. Dengan adanya fungsi tersebut maka Disporapar Kabupaten Kendal kususnya bidang pariwisata memiliki strategi daya tarik wisata sebagai strategi optimalisasi pada masa pandemi. Berdasarkan uraian latar belakang permasalahan tersebut maka peneliti mengangkat judul "Optimalisasi Pengelolaan Daya Tarik Wisata (DTW) pada Masa Pandemi oleh Disporapar Kabupaten Kendal". Tujuan dilakukan penelitian ini adalah untuk 


\section{Journal Publicuho}

ISSN2621-1351 (online), ISSN 2685-0729 (print)

Volume 4 Number 3 (August - October), (2021) pp. 854-863

Accredited SINTA SK.NOMOR 28/E/KPT/2019

Open Access at:http://ojs.uho.ac.id/index.php/PUBLICUHO/index $10.35817 / j p u . v 4 i 3.19760$

menganalisis dan mendeskripsikan bagaimana dan apa saja faktor-faktor yang mempengaruhi optimalisasi pengelolaan Daya Tarik Wisata (DTW) pada masa pandemi oleh Disporapar Kabupaten Kendal.

\section{METODOLOGI}

Penelitian ini menggunakan metode kualitatif, dalam bukunya Lexy J. Moleong yaitu Bogdan dan Taylor (2002: 3) mendefinisikan metodologi kualitatif sebagai prosedur penelitian yang menghasilkan data deskriptif berupa kata-kata tertulis atau lisan dari orang-orang dan perilaku yang dapat diamati. Menurut mereka, pendekatan ini diarahkan pada latar dan individu atau organisasi ke dalam variabel atau hipotesis, tetapi perlu memandangnya sebagai bagian dari sesuatu keutuhan.

Kemudian data yang digunakan pada penelitian ini yaitu jenis data primer dan sekunder. Menurut Riadi (2016), data primer adalah data yang berasal dari sumber asli atau tidak melalui perantara data diperoleh berupa opini pendapat dari Kepala Bidang pariwisata Disporapar Kabupaten Kendal dengan mengajukan pertanyaan wawancara sebagai informan. Kemudian menurut Riadi (2016), data sekunder adalah informasi kedua yang sudah dikumpulkan serta sudah diolah, data sekunder dapat diperoleh dari beberapa sumber misalnya jurnal, buku, literature, data stastistik dan data materi yang menunjang. Pemilihan informan sebagai sumber data dalam penelitian berdasarkan atas subjek yang menguasai masalah memiliki data dan bersedia memberikan informasi lengkap serta akurat, informan sebagai sumber data mampu memerikan informasi yang harus memenuhi syarat yang akan menjadi informan. Dalam hal ini informan yaitu Kepala Bidang Disporapar Kabupaten Kendal.

Metode pengumpulan data yang digunakan dalam penelitian ini adalah menggunakan metode pengamatan, wawancara dan dokumentasi terhadap subyek penelitian. Menurut Nawawi (2001: 100) observasi bisa diartikan sebagai pengamatan dan pencatatan secara sistematis terhadap gejala yang nampak pada obyek penelitian. Kemudian Moleong (2002: 135) mengungkapkan bahwa wawancara adalah percakapan dengan maksud tertentu. Percakapan dilakukan oleh dua pihak, yaitu pewawancara yang mengajukan pertanyaan, dan yang diwawancarai, yaitu pihak yang memberikan jawaban atas pertanyaan tersebut. Selanjutnya, Moleong (2002: 137) mengungkapkan bahwa dokumen adalah setiap bahan tertulis ataupun film lain dari rekaman yang tidak dipersiapkan karena adanya permintaan dari seorang penyelidik. Dalam penelitian ini teknik dokumentasi berfungsi sebagai pelengkap data yang digunakan untuk memperoleh data berupa dokumen-dokumen. 
Teknik analisis data yang digunakan pada penelitian ini yaitu menggunakan metode non statistik yaitu analisis data deskriptif artinya dari data diperoleh melalui penelitian tentang Optimalisasi Pengelolaan Daya Tarik Wisata (DTW) pada Masa Pandemi oleh Disporapar Kabupaten Kendal. Kemudian dianalisis secara deskriptif untuk mendapatkan gambaran mengenai fakta yang ada. Menurut Miles \& Huberman (1992: 16) analisis terdiri dari tiga alur kegiatan yang terjadi secara bersamaan yaitu; reduksi data, penyajian data, penarikan kesimpulan/verifikasi.

\section{HASIL DAN PEMBAHASAN}

\section{Optimalisasi Pengelolaan Daya Tarik Wisata (DTW) pada Masa Pandemi oleh Disporapar Kabupaten Kendal}

Undang-Undang Republik Indonesia Nomor 10 tahun 2009 tentang kepariwisataan menyebutkan bahwa daya tarik wisata adalah segala sesuatu yang memiliki keunikan, keindahan dan nilai berupa keanekaragaman kekayaan alam, budaya dan hasil buatan manusia yang menjadi sarana atau tujuan kunjungan wisatawan. Daya Tarik Wisata (DTW) yang dibahas dalam penelitian ini dikelola oleh Dinas Kepemudaan Olahraga dan Pariwisata Kabupaten Kendal. Kepala Bidang Pariwisata Disporapar Kabupaten Kendal mengatakan bahwa Kendal memiliki potensi luar biasa, sebab memiliki wilayah yang kaya akan potensi wisata alam dan religi. Selain itu juga didukung letak geografis, yang memiliki wilayah pantai dan dataran tinggi seperti pegunungan dan pantai, perkebunan maupun persawahan jika dimaksimalkan maka akan mengangkat ekonomi masyarakat. Disporapar pernah melaksanakan Pelatihan Tata Kelola Pariwisata kepada empat puluh pengelola wisata dari lima belas destinasi wisata. Dengan tujuan pelatihan ini adalah mengajak semua stakholder kepariwisataan untuk menjadikan Kendal sebagai salah satu daerah tujuan wisata di Jateng, setelah Borobudur sebagai salah satu destinasi nasional. Berikut ini adalah daftar data Daya Tarik Wisata (DTW) Kabupaten Kendal:

Tabel 1. Data Daya Tarik Wisata (DTW)

\begin{tabular}{cl}
\hline No & \multicolumn{1}{c}{ NAMA DAN BIDANG USAHA } \\
\hline 1 & Air Terjun Curugsewu \\
\hline 2 & Goa Kiskenda/Kiskenda Caves \\
\hline 3 & Kolam Renang Boja/Boja Swimming pool \\
\hline 4 & Curug Panglebur Gongso / Panglebur Gongso Waterfall \\
\hline 5 & Pelabuhan Baru Kaliwungu/The Harbour of Kendal Regency \\
\hline 6 & Pantai Cahaya \\
\hline 7 & Agro Wisata Tirto Arum/Tirto Arum Baru Tourism Agro \\
\hline 9 & Pemandian Air Panas Nglimut \\
\hline 10 & Pantai Sendang Sekucing/Sendang Sekucing Beach \\
\hline 11 & Agro Wisata Kebun Teh Medini/Medini Tea Walk Tours
\end{tabular}




\section{Journal Publicuho}

ISSN2621-1351 (online), ISSN 2685-0729 (print)

Volume 4 Number 3 (August - October), (2021) pp. 854-863

Accredited SINTA SK.NOMOR 28/E/KPT/2019

Open Access at:http://ojs.uho.ac.id/index.php/PUBLICUHO/index $10.35817 / j p u . v 4 i 3.19760$

\begin{tabular}{cl}
12 & Pantai Ngebum Kaliwungu/Ngebum Beach of Kaliwungu \\
\hline 13 & Plantera Fruit Paradise \\
\hline 14 & Pabrik Gula Tjepiring \\
\hline 15 & Tirta Nusantara Water Boom \\
\hline 16 & Citra Asri Gonoharjo \\
\hline 17 & Makam Wali Gembyang \\
\hline 18 & Makam Wali Joko \\
\hline 20 & Makam Wali Hadi \\
\hline 21 & Makam Tumenggung Mangeran Djuminah, Sunan Katong, Pakuwojo \\
\hline 22 & Makam Sunan Abinowo \\
\hline
\end{tabular}

Melalui tabel 1 di atas, dapat diketahui bahwa Kendal memiliki 22 tempat wisata yang terdiri dari pegunungan, air terjun, pantai, wisata religi sampai wisata buatan berbentuk wahana permainan. Namun, sejak terjadinya pandemi Covid-19 wisatawan lokal maupun luar daerah tidak terlalu banyak. Kepala Bidang Pariwisata Dlsporapar menyatakan bahwa pandemic Coivd-19 membuat penurunan daya tarik wisata, sehingga pelaku wisata dituntut untuk berinovasi dalam penyesuaian pandemi ini. Selain itu juga memberikan dampak penurunan pendapatan asli daerah. Penelitian Yakup (2019) mengungkapkan bahwa pariwisata berpengaruh positif terhadap pertumbuhan ekonomi dan sebaliknya pertumbuhan ekonomi berpengaruh positif terhadap pariwisata.

Adapun strategi Disporapar Kabupaten Kendal dalam pelaksanaan optimalisasi pengelolaan daya tarik wisata (DTW) pada masa pandemi yakni seperti menerapkan protokol kesehatan dengan membentuk SOP yang harus dijalankan di setiap detinasi. Seperti menyiapkan sanitasi dan pengukuran suhu pada pengunjung. Kemudian mengadakan pelatihan dan edukasi kepada para pelaku wisata tentang pentingnya protokol kesehatan dalam pengelolaan destinasi setelah adanya pandemi. Selanjutnya untuk kenyamanan dan keyakinan wisatawan khususnya yang dari luar daerah dan mancangera, destinasi wisata diharapkan mendapat sertifikat CHSE (Cleanliness, Health, Safety, Environment Sustainability).

Sejalan dengan penelitian lain yang telah dilakukan oleh Ida Bagus (2020) yang berjudul New Normal Bagi Pariwisata Bali di Masa Pademi Covid-19 yang menunjukkan bahwa pariwisata di masa pandemi harus dioptimalkan dengan melaksanakan strategi pemulihan pariwisata. Seperti yang dilakukan di Bali dalam new normal diantaranya, menerapkan standar kebersihan dan keamanan yang memadai bagi wisatawan, memberikan alternatif pola berwisata baru: staycation, niche tourism, solo travel tour, wellness tour, virtual tourism. Kemudian Dian Herdiana (2020) dalam penelitiannya mengenai rekomendasi kebijakan pemulihan pariwisata pasca wabah Covid-19 di Kota Bandung menyatakan bahwa pemulihan pariwisata terdiri dari optimalisasi peran kedua sektor utama pariwisata, yaitu pemerintah kota Bandung sebagai otoritas resmi yang memiliki hak untuk 
menyusun kebijakan pemulihan dan para pelaku usaha sebagai pihak penyelenggara kegiatan pariwisata dengan melakukan usaha pemulihan secara internal maupun eksternal. Dapat disimpulkan bahwa pemulihan pariwisata bergantung pada pemerintah dan pelaku usaha dalam melakukan rencana strategi optimalisasi.

\section{Faktor-faktor yang mempengaruhi}

\section{Kekuatan (Strenght)}

Dalam melaksanakan optimalisasi terdapat faktor-faktor strategis yang mempengaruhi keunggulan daya tarik wisata Kabupaten Kendal seperti keunggulan unsur geografi yang lengkap mulai dari pantai, dataran tinggi, pegunungan dan buatan yang selama ini belum di eksplor secara maksimal. Keunggulan tersebut membuat tingginya ketertarikkan wisatawan, namun karena pandemi covid-19, mengakibatkan adanya larangan untuk pergi ke luar daerah sehingga berakibat ditutupnya tempat wisata beberapa waktu yang lalu. Selain itu, Disporapar Kabupaten Kendal juga melakukan penambahan fasilitas kebersihan umum seperti tempat cuci tangan dengan sabun dan beberapa tempat duduk sedikit dirubah agar memenuhi unsur jaga jarak diantara pengunjung karena masih tingginya angka penularan covid-19 dan kekhawatiran timbulnya klaster baru pada destinasi wisata. Dengan adanya hal tersebut diharapkan optimalisasi daya tarik wisata diharapkan mampu bertahan di tengah situasi pandemi.

\section{Kelemahan (Weakness)}

Hambatan yang dihadapi dalam melaksanakan optimalisasi pengelolaan daya Tarik wisata pada masa pandemi yakni regulasi dari pemerintah tentang pembatasan jam buka untuk destinasi wisata bahkan ada himbavan untuk ditutup sementara waktu. Usaha yang dilakukan untuk mengatasi hambatan tersebut adalah dengan menunjukkan bahwa destinasi kita aman untuk dikunjungi, dengan menambahkan fasilitas pengecekan suhu tubuh, kewajiban untuk memakai masker, tersedianya tempat cuci tangan dengan sabun dan air yang mengalir termasuk juga pembertahuan untuk menjaga jarak. Dengan adanya upaya tersebut, diharapkan agar destinasi wisata tetap dibuka dengan ketentuan protokol kesehatan yang telah dianjurkan oleh pemerintah.

Yang menjadi kelemahan lain yaitu pelaku usaha industri pariwisata belum memaksimalkan pemanfaatan teknologi digital, sehingga hal ini melemahkan pelaku usaha dalam meningkatkan perekonomian di tengah pandemic. Padahal teknologi digital merupakan solusi yang bisa digunakan oleh para pelaku usaha di bidang pariwisata agar bisa bertahan dan bangkit dari keterpurukan akibat pandemi covid-19. Selain itu juga mengembangkan wisata melalui pengenalan secara virtual melalui media sosial.

\section{Peluang (Opportunity)}

Pada kesempatan di tengah pandemi covid-19, Disporapar Kabupaten Kendal melalui Kepala Bidang Pariwisata berharap agar pandemi ini segera berlalu. Sehingga minat 


\section{Journal Publicuho}

ISSN2621-1351 (online), ISSN 2685-0729 (print)

Volume 4 Number 3 (August - October), (2021) pp. 854-863

Accredited SINTA SK.NOMOR 28/E/KPT/2019

Open Access at:http://ojs.uho.ac.id/index.php/PUBLICUHO/index

10.35817/jpu.v4i3.19760

masyarakat untuk berwisata diharapkan meningkat. Hal ini yang harus bisa dimanfaatkan oleh para pelaku wisata. Melihat bahwa yang sedang menjadi tren saat ini pada daya tarik wisata adalah adanya tempat selfi yang unik dan menarik yang sering muncul di instagram, facebook, twitter, dan media sosial lainnya. Ini dapat menjadi peluang dari pelaku wisata untuk mempersiapkan daya tarik wisata setelah pandemi berakhir.

Adapun peluang lain yang harus dilihat pada masa pandemi seperti upaya pembenahan sektor pariwisata yang dapat dilakukan oleh pemerintah dengan membuat promosi melalui kunjungan virtual, pendekatan ini dapat dipakai untuk mensosialisasikan dan promosi awal kepada calon konsumen potensial. Penggunaan teknologi fotografi 360 dan kunjungan virtual dapat menjadi strategi pemasaran di sektor pariwisata (Sulaiman et al., 2020). Pendekatan seperti ini menciptakan peluang baru bagi pelaku usaha untuk dapat mengoptimalkan daya tarik wisata.

\section{Ancaman (Threat)}

Dengan adanya pademi covid-19 yang belum juga berakhir, Disporapar Kabupaten Kendal bersama pelaku usaha khawatir usaha pariwisata dan minat masyarakat terhadap Daya Tarik Wisata di Kabupaten Kendal menurun. Penurunan tersebut juga dikhawatirkan berdampak pada Pendapatan Asli Daerah (PAD) dan juga penurunan wisatawan dalam ketertarikannya terhadap Daya Tarik Wisata (DTW) karena takut terpapar virus covid-19. Dengan kata lain Daya Tarik Wisata memiliki potensi sebagai klaster virus dikarenakan menciptakan keramaian dan kerumunan, sehingga pelaku usaha harus disiplin dalam menerapkan protokol kesehatan.

Sejalan dengan penelitian Saena (2021) yang mengungkapkan bahwa para pelaku industri pariwisata ada yang terpaksa menutup usaha dan ketika buka kembali sudah tidak seperti sebelumnya, karena pengunjung yang tidak ada atau berkurang sehingga menyebabkan pendapatan ekonomi pelaku usaha yang menurun. Sehingga bantuan dari pemerintah kepada masyarakat dan para pelaku usaha sangat dibutuhkan agar mampu bertahan serta mampu beradaptasi dengan kebiasaan baru di tengah pandemi covid-19. Dengan kata lain, hal ini menjadi ketakutan pelaku usaha dalam malanjutkan usahanya, karena setelah pandemic berakhir mereka tidak bisa langsung bangkit, namun bermula perlahan menyesuaikan diri kembali. 


\section{KESIMPULAN}

Berdasarkan hasil penelitian dan pembaasan yang telah dilakukan, maka dapat dibuat kesimpulan sebagai berikut :

1. Optimalisasi pengelolaan Daya Tarik Wisata (DTW) pada masa pandemi oleh Disporapar Kabupaten Kendal sudah berjalan dengan baik dan efektif, sesuai anjuran pemerintah dengan menerapkan disiplin protokol kesehatan. Seperti menyediakan tempat cuci tangan, mengatur jarak tempat duduk dan mewajibkan pengunjung untuk menggunakan masker.

2. Dalam rangka optimalisasi Daya Tarik Wisata (DTW), Disporapar Kabupaten Kendal menyelenggarakan pelatihan tata kelola pariwisata kepada pelaku wisata dengan tujuan agar pelaku wisata mampu mengangkat destinasi wisata Kabupaten Kendal dikenal oleh wisatawan dan masyarakat luas.

3. Disporapar Kabupaten Kendal melalui Kepala Bidang Pariwisata menganjurkan pelaku wisata untuk memiliki sertifikasi CHSE (Cleanliness, Health, Safety, Environment Sustainability) untuk mendapatkan kepercayaan dan kenyamanan wisatawan.

4. Pelaku usaha mengarapkan agar pandemi covid-19 segera berlalu agar destinasi wisata dibuka dengan bebas khawatir akan adanya klaster penyebaran.

5. Pelaku usaha Daya Tarik Wisata (DTW) khawatir apabila pemerintah menerapkan kebijakan untuk menutup destinasi wisata untuk sementara. Karena hal ini mempengaruhi pendapatan pelaku wisata dan juga pedagang-pedagang yang termasuk ada didalamnya.

\section{Rekomendasi}

Sesuai dengan kesimpulan di atas maka penulis dapat memberikan rekomendasi kepada Disporapar Kabupaten Kendal dalam hal optimalisasi pengelolaan Daya Tarik Wisata pada masa pandemi, sebagai berikut :

1. Disporapar perlu melakukan pengawasan dan evaluasi secara berkala destinasi Daya Tarik Wisata khususnya pada fasilitas-fasilitas umum tambahan seperti cek suhu, tempat cuci tangan dan penggunaan masker, karena pelaku wisata terkadang lalai dengan kedisiplinan protokol kesehatan.

2. Pelaku wisata sebaiknya diberikan pelatihan strategi pemasaran destinasi secara online. Karena dengan memanfaat teknologi digital, maka akan meningkatkan daya saing yang lebih efisien untuk dapat dikenal oleh masyarakat luas.

3. Disporapar diharapkan untuk bisa menjembatani informasi mengenai sertifikasi CHSE kepada pelaku wisata melalui sosialiasi dan pelatihan. 


\section{Journal Publicuho}

ISSN2621-1351 (online), ISSN 2685-0729 (print)

Volume 4 Number 3 (August - October), (2021) pp. 854-863

Accredited SINTA SK.NOMOR 28/E/KPT/2019

Open Access at:http://ojs.uho.ac.id/index.php/PUBLICUHO/index

$10.35817 / j p u . v 4 i 3.19760$

\section{REFERENSI}

Undang-Undang Nomor 10 Tahun 2009 Tentang Kepariwisataan.

. 2004. Undang-Undang Nomor 23 Tahun 2014 Tentang Pemerintah Daerah.

Dappa, Saena, dkk. 2021. Pandemi Covid-19 Terhadap Sektor Pariwisata Negeri di Atas Awan di Desa Benteng Mamullu Kecamatan Kapala Pitu Kabupaten Toraja Utara. https://ejournal.unsrat.ac.id/index.php/holistik/article/view/34466/32361

Dian Herdiana. 2020. Rekomendasi kebijakan pemulihan pariwisata pasca wabah corona virus disease 2019 (covid-19) di kota Bandung. Jurnal Jumpa, Volume (7), Nomor 1

Dinas Kepemudaan, Olahraga dan Pariwisata Kabupaten Kendal. 2020. Data Pariwisata, diakses dari https://disporapar.kendalkab.go.id/

Enceng, Aries Djaenuri. 2018, Sistem Pemerintahan Daerah. Banten Universitas Terbuka

Miles dan Huberman. 1992. Analisis data Kualitatif. (diterjemahkan Ole: Tjetjep Rohedi Rosidi).

Moleong, J, Lexy. 2002. Metodologi penelitian Kualitatif. Bandung: PT. Remaja Rosdakarya

Nawawi, Hadari. 2001. Manajemen Sumber Daya Manusia untuk Bisnis yang Kompetitif. Cetakan Keempat. Penerbit Gadjah Mada University Press, Yogyakarta

Pendit, Nyoman S. 2003. Ilmu Pariwisata Sebuah Pengantar Perdana. Jakarta:Pradya Paramita

Peraturan Daerah Nomor 76 Tahun 2016 tentang Kedudukan, Susunan Organisasi, Tugas dan Fungsi, serta Tata Kerja pada Dinas Kepemudaan, Olahraga, dan Pariwisata Kabupaten Kendal

Radika Ayu Errawati. 2019, Peran Dinas Kepemudaan, Olahraga, dan Pariwisata Dalam Pengelolaan Objek Wisata Curug Sewu Untuk Peningkatan Pendapatan Asli Daerah Kabupaten Kendal, Jurusan Politik dan Kewarganegaraan, Fakultas IImu Sosial, Universitas Negeri Semarang, diakses dari https://lib.unnes.ac.id/33972/1/3301415008maria.pdf

Riadi, Edi. (2016). Statistika Penelitian (Analisis Manual dan IBM SPSS). Edisi 1. Yogyakarta: ANDI.

Sailendra, Hanief. 2020. Disporapar Kendal: Didukung Letak Geografis, Wisata di Kendal Miliki Potensi Besar untuk Dikembangkan, diakses dari https://halosemarang.id/disporaparkendal-didukung-letak-geografis-wisata-di-kendal-miliki-potensi-besar-untukdikembangkan

Yakup, A. P. 2019. Pengaruh Sektor Pariwisata Terhadap Pertumbuhan Ekonomi Di Indonesia. Universitas Airlangga Surabaya. https://drive.google.com/file/d/10tF5Tpbaelal-xx R6cWjlY Fczlex8/view? Usp=drivesdk 